\title{
TRANSFORMATIONS IN RETAILING: \\ TOWARD THE 'R' ESTABLISHMENT
}

\author{
Panos Apostolidis \\ Walter Pachuk \\ University of Scranton \\ Scranton, PA
}

\section{Introduction}

Various theories have attempted to explain institutional change and development in retailing based on cyclical or environmental phenomena ([19], [12], [8]). These theories have contributed much in retail management although they have not been empirically tested. A brief review is cited later on.

It is the intent of this article to show that environmental changes indeed take place in the retail world and that several transformations subsequently occur. It could be argued, however, that these transformations are not the result of theoretical propositions or scientific inquiries. They, rather, are the result of precipitous, hasty responses of individual retailers who try to economize in energy costs, to scramble their merchandise, to upgrade their services or delivery, and to ultimately remain competitive. This is called "innovation and creativity" by the authors, not transformations.

The thrust of the article is on presenting a prescriptive and synthesized conceptual approach that may guide retail management in the formation of new outlets and in transforming old ones in terms of structure, layout, and functions. The main theme borrows heavily from organization theory, where propositions for new establishments have been advocated on the basis of descriptive models, self-designing systems, and other dynamics [24].

Marketers have not systematically tackled the problems of institutional change (and store development) that represent new frontiers for transformations. Most of the theories of retailing are cyclical theories which fall into the "Wheel" theories of institutional change.

\section{Review of Early Theories}

McNair [19], the so-called father of the Wheel of Retailing, has offered an early theory concerning the growth and development of retail institutions. He stated that new types of retailers enter the market as a low-margin, low-price, low-status retailers. Gradually, these new types add to their operating costs by providing new services and by improving their facilities. Then, over time, they become high-cost retailers vulnerable to competition. Critics against this have eluded that new retail institutions are led by cost-conscious, hard-working entrepreneurs who are profit maximizers with

Journal of Business Strategies, Volume 6, Number 2 (Fall 1989) 
no interest in providing unprofitable services. McNair and May [20], in a later paper admitted some of the deficiencies. Not all retailing institutions in the Urited States have begun as a low-cost, low-margin, price-oriented firm. Vending machines, for example, have always been a high-cost form of distribution as well as many of the contemporary innovations such as boutiques, specialty stores, health food stores, etc.

Hollander [12] contended that the Wheel of Retailing was not quite relevant as a theoretical explanation of retail growth, development, and change. His theory has been based on the premise that retail institutions evolve from broad-based retailers with wide assortments to transform into retailers offering specialized, narrow lines. Then, over time, the retailers begin again to offer a wide assortment, thereby developing a renewal - general - specific pattern. Hollander later modified his theory asserting that instead of comparing retailing to an accordion, we might better compare it to an orchestra or to a band of accordion players. Indeed, he moved from a simple theory of assortment mixes to a larger notion - a theory of retail growth and development.

Davidson et. al. [8] described the institutional life cycle as having four stages. The first stage is characterized by the emergence of a new retailing institution. In the second stage, both sales volume and profits attain high rates of growth. A widespread expansion into new geographic territories takes place and new entrants are rapidly attracted. Market share and profitability of the innovating firms increase steadily. By the end of the period, the favorable factors tend to be counterbalanced by cost pressures that arise from a larger staff, complex internal systems, more management controls, and diseconomies of large scale multi-unit organizations. In the maturity state, market share declines whereas managers find it more difficult to control their firms. Consequently, managerial effectiveness is decreased. During the final stage of decline and death, a loss in market share occurs. Profits are almost non-existent. Managers find that their managerial effectiveness has diminished and they try to develop new retail concepts designed to, once again, become a dominant force.

Today, the evolutions in retailing occur at a faster pace and the transformations are more complex beyond the conventional changes in store layout, merchandise mix, and location. There are expectations that the Post Office will deliver fewer regular letters as electronic mail becomes more popular; bookstores already sell audio-visual texts as well as the printed ones; Prudential Insurance may soon manufacture and market new houses (the Japanese do it now in two-hours time); Multi-Sclerosis groups may eventually operate hospitals; McDonald's may sell hamburgers from luxurious vans in town squares; going to the movies has been long ago replaced by having movies come to us. These are a few examples of the transformations evolving in retailing and the society in general.

With such a foundation, the article attempts to: (a) propose the formation of new outlets with focus on organizational propositions and managerial impetus rather than incidental actions of retail managers; (b) highlight several environmental phenomena and forces which may cause the transformations in retailing; and (c) discuss some of the sporadic, diverse responses of retailers to cope with. 


\section{A Novel Retail ' $R$ ' Establishment}

The authors have conceived the notion of a novel retail establishment to be designed on the basis of organization theory, contemporary consumer input, and new life styles. It is a proposal for viewing the new stores and retail outlets as self perpetuating, flexibly structured, and continually adaptive models to recurrent envi ronmental changes. These new structures may be temporarily labeled Retail ' $R$ ' Establishments.'

The proposed innovative retail outlet can be designed and organized on postulates derived partially from organization theory and partially from adapted Japanese Management. The proposition can be understood if we refer for a moment to theory type $Z$. Theory type $Z$ has been proposed by Ouchi and Jaeger [23] as a compromised blend of theories type A (American) and type $J$ (Japanese) to serve as an alternative to American management. As known, the Japanese $(J)$ advocate life time loyalty among other things - whereas the Americans (A) focus on immediate gains. Similarly, in the proposed model, the extreme values of American and Japanese management and life styles have been modified to display average values.

The authors propose the inception and understanding of a Retail ' $R$ ' Establishment which could possess certain fundamental elements or characteristics. The assigned values on these elements would come from compromising on bipolar extremes and contrasting notions. The average points on a scale could determine the character and structure of the 'new outlet.' See Figure 1.

The extreme bipolar values would have two opposite ends. The choices are rated at the point ' $R$ ' between: a transitive, self-adapting establishment-versus- a permanent one; having continuous consumer input -versus-being delegated by rigid management decision making; gaining lifetime customer loyalty -versus-achieving short term patronizing; based on a totality of responsibilities -versus-autocratic management achievements; operating on informal basis -versus- striving on formal rigidity; to ultimately remain flexible and technological-versus- stagnant and antiquated.

Specifically, the major properties of the new Retail ' $R$ ' Establishment may be described in the following passages:

1. The ' $R$ ' Establishment may maintain the capacity to change itself in form, size, and location in order that as the market shifts, the appropriate adjustments can be made.

${ }^{1}$ Most of the above material is elaborated from organization theory. See, Bo L. T. Hedberg, Paul C. Nystrom, and William H. Starbuck, "Designing Organizations to Match Tomorrow," in Ptescriptive Models of Organizations, North/Holland/TIMS Studies in the Management Seienes 5 , ed. P.C. Nystrom and W. H. Starbuck (1977), 171-81; Karl Weick, "Organization Design: Organizations as Self-Designing Systems," Organizational Dynamics 6 (Autumn 1977), 30-46; and Bo L. T. Hedberg, Paul C. Nystrom, and William H. Starbuck, "Camping on Seesaws: Prescriptions for a Self-Designing Otganization," Administrative Seience Quarterly 21 (1976), 41-65. 


\section{Figure 1}

\section{A Comparison Between the ' $R$ ' Establishment and ' $C$ ' Competition}

Continuous consumer ..... 'R' .... $\mathrm{C} \ldots \ldots$. Rigidity in understanding input

needs

Transitive, self-

Permanent, solid in adjusting

structure

Modern, technological

' $R$ '

C

Antiquated, old

Pleasant interior with ' $R$ '

$\mathrm{C}$ Inferior in atmosphere surprises in merchandise ${ }^{a}$

Leadership in newest, latest $\ldots$. ' $R$ ' ... C ... ... Slow moving, me-too assortments

Customizing, tailored, and ' $\mathrm{R}$ ' C Ready made, nontargeted services uniform items

Distinctive events, wide ' $R$ ' Traditional shopping

High degree of repeat C Low loyalty customers

Connecting home ' $R$ ' $\ldots .$. Standing apart

Helpful with informal ' $R$ ' $\mathrm{C}$ Too much informality dialogue

Fair values, pricing C Unfair and quality

Friendly salespersons ' $R$ ' $\mathrm{C}$ Unfriendliness

Customer satisfaction ' $R$ ' Managerial profit orientation motive

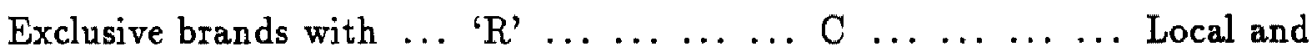
global rights regional

${ }^{a}$ Adopted in part from Cravens, et. al. [7]. 
For example, Marriott hotels can vary the footage of their ballrooms to accommodate from 50 up to 1200 guests. Meals on wheels move now around and change locations invariably. Funeral services are performed inside buses where the relatives are seated in a circle to avoid driving to the cemetery. Ice cream parlors sell soups during the winter. Nabisco claims that cold cereal can be warmed-up in the microwave oven to be (perhaps) positioned against soups and sold in fast food outlets.

2. The ' $R$ ' Establishment may allow consumer input in store layout, merchandise selection, opening hours, price setting, and overall operations.

For example, the clients of the new store may request openly and in dialogue certain changes. The store will avail suggestion boxes, informal dialogue with the salespersons, continuous consumer research, and catering to tastes of the patrons. This means a greater empathy to satisfy the consumer - and especially those consumers who still love to shop.

3. The ' $R$ ' Establishment may retain the values of consumer individualism in shopping with responsibility coming from concensual processes by both management and clientele with minimal profit exploitation.

For example, typical personality motives of shoppers include role playing, sensory stimulation, physical activity, and self-gratification [17]. Shopping should provide diversion, i.e., the opportunity to find what is new in clothing, electronics, foods, or other items, at fair pricing. New establishments are designed to provide such a sensory stimulation via store decor and merchandise arrangement emphasizing individuality and the increased importance of leisure time to the consumer.

4. The ' $R$ ' Establishment may connect home, place of employment, and place of purchasing by information technology and consumer awareness while maintaining the home as the center of living.

For example, advances such as two-way cable and personal computers allow consumers to shop from the comfort of their own homes and to sense the stimulation and satisfaction associated with shopping. Customers are able to view merchandise on command by calling up tapes on in-home TV monitors and to communicate directly with the store. Computers process the sale and activate the billing procedure. Other changes in consumer lifestyles, increased leisure time, and the desire for convenience have brought direct marketing.

5. The ' $R$ ' Establishment may promote a holistic concern for members and their families as a retail institution caring for affiliation and customer loyalty in sharing the shopping pleasures and fulfilling their needs. 
For example, the new stores may sustain the individual goals of consumers by enhancing those activities that patrons perceive to be associated with their personalities and life roles, i.e., I-am-me, self gratification, and other evolving concepts in modernized outlets.

Technically, this Retail ' $R$ ' Establishment can be designed and structured as a 'transitive and self adjusting' outlet with a commitment to serve the dynamic retail world of the next decades. It has been advocated that such management approaches can be employed in macromarketing with the assumptions that macro changes can be managed or at least guided; that managers' purposeful actions can become major causes of change; and that there are such intentions by management to seek causal explanations and influences [29].

\section{Environmental Phenomena and Changes}

Retailers, as survivors, are required to adapt to the shifts and changes of the environment. They can monitor, manipulate, and respond properly at least to three areas of anticipated modifications: (1) technological advances, the machines and work processes; (2) consumers, their changing demographics, attitudes, beliefs and values; and (3) structure, form, and merchandise assortment of the establishment. Consequently, flexible innovative organizational structures with advanced communication systems and open consumer input will be necessary for the future.

\section{Technological Changes}

Some of the changes which have appeared in the area of technology are breakthroughs in genetic biochemistry, robotics, solar fusion, heat resistant ceramics, computer microchips, laser beams, and space technology. These are forces that can be harnessed to serve human needs and even reverse the negative effects of earlier abuses [10]. Biomass, or organic materials from plants such as bagasse, can produce thermoelectric power to replace oil.

Assembly lines or self-service outlets, long the symbol of an industrial age, have been replaced by Toffler's [25] process of demassification. Economies of scale have been achieved by using lasers, computers, and other technologies. In many stores, video and terminals have altered shopping. Catalog showrooms may require restructure. Displays have substituted warehousing with direct shipments from the manufacturer. With fuller use of home computers, commuting time may be minimal.

\section{Changes in Consumer Values}

Values and attitudes have undergone a strong mutation. The ideology of growth has been changed to expectations of decay, of abundance to scarcity, and of consensus to conflict. The quiet ego revolution has become the goal of many individuals as citizens seek to fulfill their human potential. The search for peak experiences, inner-peace, and greater understanding are different from the activism of the $60 \mathrm{~s}$ and the "me" decade of the 70s. Retail shifts are manifested in fast serving places, smaller packages, lighter materials, and time and cost savings. Modern retail outlets 
reflect the values of consumer individualism by connecting home, work, and shopping altogether.

Our cultural values are most often aligned with the goals of an affuent economy; that is, a rewarding performance with material payoffs and rich life styles through patterns of consumption [3]. The spirit of affluence surrounds such American cultural rites, as weddings and Bar Mitzvahs which bring in new ways of lavishly catering. Consumers on the other hand have become thrifty in their choices of products and services. The intelligent retailers can take advantages of both trends by adjusting their offerings to specific consumer groups [17].

\section{Changes in Structure and Form}

Changes are also anticipated in the economy with concerns in sharing giobal resources and know-how. We used to harness the scientific achievements in order to restructure the environment and satisfy our desires. New ideologies have emerged now. Western thought presumes that the natural state of the world is chaos and that man's role is to provide order through rational activity. A continuous battle between the forces of good and evil is waged in the process. Eastern thought takes an opposite position, assuming that the natural state of the world is order, not chaos. Man's role is to place himself in a harmonious relationship with the other elements of nature.

The energy situation has influenced window size, entrance design, insulation measures, heating and power units, and even the position of the building. Transition means to pass from one condition or place to another. Transmutation means to change one form, nature, substance into another. Both terms apply to retailing [2]. Space management is a major concern of marketing making consumer input necessary for store layout, merchandise selection and setting open-close hours.

During the past several years, a number of technological advances have already been adopted by innovative outlets as the result of growing computerization [4].

The major technological advances include:

1. Computerized checkout systems (UPC or OCR-A) that speed up transactions, record data, and reduce cashier errors.

2. Anti-shoplifting tags attached to merchandise to set off an alarm, if not properly removed by employees.

3. Automatic energy-control systems that carefully monitor store temperature and reduce fuel costs.

4. Site-selection programs which can evaluate the savings from alternative store locations.

5. Improved credit systems that allow faster processing of credit authorizations and transfers of funds.

6. Computerized inventory systems that reduce the need for physical inventory counts. 
In general, such technological advances enable retailers to improve efficiency, obtain information faster, hold down labor costs, minimize losses due to theft, and to make profits.

\section{Sporadic Responses: The Metamorphosis Occurs}

Many retailers of the 1990 s will develop aggressive response strategies. One challenge will be to make consumers perceive their retail outlets as destination stores rather than convenience stores. Destination stores are units where selection and uniqueness of merchandise act as magnets for customers. As such, they are distinguished from their counterparts which are primarily patronized because of convenience. Bloomingdale's flagship unit in New York is an outstanding example. At the other end of the spectrum, wholesales clubs appealing on price, such as BJ's, Sam's PACE, and Costco are blooming. According to Loeb [14], the retailers that will prosper in the future are those who can define and project a destination store image.

Another illustration, is Tasca Lincoln-Mercury in Massachusetts with its cramped showroom-garage, with salesmen who look like sharks, and with mechanics who are scruffy. Tasca has become successful by adapting to its environment and developing a tremendous consumer loyalty because of its customer service. Tasca delivers vehicles in sparkling clean condition, it meets schedules, and keeps service appointments. It also has valet parking when customers pick up their vehicles, has salespeople who make follow-up calls after sales, and gives monthly bonuses to personnel who scored highest in customer satisfaction surveys [22].

To maintain its position as a large supermarket chain, Safeway has embarked on an aggressive strategy. The firm has been "going up-scale" through its Bon Appetit stores that feature gourmet foods, a large selection of fine wines, exotic produce items, and sizable floral departments [26].

Major chains are blazing trails into small town America. In Lowe's Home Centers, the staff is trying to know customers on a first-name basis because people practically demanded that a store be opened in Buffalo, Missouri. According to the manager of the scaled-down $29,800 \mathrm{sq}$. ft. store people are just happy to have a store where they can get $90 \%$ of their needs avoiding to drive into the city $[21]$.

J.C. Penney recently introduced their video-ordering system in the Chicago area cable television subscribers. Members are wired to Telaction's "black box," and after the television is on, they can select from a menu the product/service category/item and the name of the retailer to buy from [11].

Retailers are also competing in a market characterized by maturity, overcapacity, intense price competition, and an essential "sameness" among stores. All these forces were once reserved for the so-called commodities. Not only are store types looking less and less different from one another, but a growing range of store types is selling the same kinds of merchandise [27]. These retailers will need new strategies to be successful. 
There are major and minor transformations evolving in retailing. In response to the shifts in the marketplace, retailers basically modernize their structures, increase their sizes, and relocate to prosper. Unfortunately, these responses seem to be isolated or divergent because they come as an immediate solution to the problems of declining markets, rising costs, etc. The authors advocate that they are not based on predictions on the evolution of markets and on the totality of forthcoming causes.

\section{Historical Retail Evolutions}

Historically, retailers have been striving to survive and prosper. In the early $1950 \mathrm{~s}$ they developed self-service shopping formats with wide aisles, bright lights and a large, varied stock of merchandise. This development revolutionized food retailing almost overnight [6]. Chain stores displaced single proprietorships and, as they did, supermarkets proliferated in suburban shopping centers.

Other past retail innovations have combined two different businesses to form a successful partnership. Albertsons and Skaggs have joined forces and opened outlets in Texas and Florida that featured full food store lines and drugstore services. Levitz pioneered the furniture warehouse concept, underpriced conventional furniture stores, and has added carpets, consumer electronics, and major appliances to its inventory.

Vigorous competition for the retailer has come from electronic communications, specifically the telephone. Phone-ordering, distribution centers, and delivery services have dealt with groceries, drugs, flower arrangements, car rentals, etc. Tele-Mart Enterprises of San Diego has launched a similar delivery system. Quarterly catalogs were sent for a membership fee and the products were shipped from the company's centralized distribution facility. The costs of personnel and equipment are partially offset by savings on physical plant leases.

Attempts for diversification have come from the addition of services. Sears has established an automobile driving school, dental services, and has added life insurance to their Allstate casualty insurance business. Marshall Field of Chicago reweaves rugs and restores oil paintings. In other stores, cooking classes are offered and beauty parlors are associated with health restaurants. It is estimated that as much as 20 percent of department store revenues will be derived from new services.

As a result, retailers have created bigger shopping centers using size to their competitive advantage [28]. Octopus stores, such as those of Kroger, have been built around huge, centrally placed food departments surrounded by sections featuring specialty items as women's fashions, children's clothing, shoes, drugs, health products, and beauty aids. The day of the behemoth had arrived; aisles stretched the equivalent of a block, displays alternated with conventional shelving, and items ranging from stationery to clothing were included [16].

Dominant business firms, because of their market position, have created significant societal consequences through their marketing activities [29]. Most of these firms have assumed macro responsibilities. 


\section{Concluding Remarks}

Adopting innovations and responding with sophistication and creativity are vitally important in retailing. Both are considered as prerequisites for success. However, radical organizational designs have not been universally propagated although have appeared as plausible responses to new technologies, humanistic values, and the macroenvironment. In the past, changes in the environment have typically occurred slowly with minor implications. Today, the pace of environmental change is accelerating at a substantial rate. The role of retail management is to find a consistent relationship between the firm and its environment. Far-sighted retailers must monitor consumer demographics, shifts in life-styles, and the progress in technology.

Most retail institutional changes do occur because of the evolving environment. For example, non-store retailing has grown fast. More firms are engaged in riskminimization retailing, whereby others strive to hold down initial investment costs as well as operating expenses. Rationalized retailing has combined highly centralized management control with rigorous operating procedures. Two opposite strategies, mass merchandising and positioned retailing, have become quite popular as more firms capitalize on the "bigness" of their stores, while others concentrate on niching smaller market segments.

Retailers (in the micro level) operate efficiently theit stores and cater satisfactorily to their clientele. However, they do not care for the totality of markets. It is the task of retail management (in the macro level) to be concerned with instituting and fostering planned transformations (of shape and place) for outlets and establishments in modern shopping. We may witness institutions (outlet conglomerates) which will reach the point where they will not only adapt to the innovations, but will also generate forms, values, and systems of their own to perpetuate themselves. The authors advocate that such a possibility is feasible and they propose the examination and study of the Retail-R Establishment which is conceived and postulated from relevant organization theories and management propositions.

\section{Epilogue}

The role of marketing is pervasive. Changes in future consumer markets will require new, unique and innovative approaches to retailing strategy. Marketing in modern retajl organizations should be more of a strategic endeavor and less of an extension of the advertising function. Strategies will have to become more aggressive and competitive by utilizing a broader range of tools than merely pricing and sales promotions. The professionalization of retailing can be enhanced by the introduction of new and fresh marketing thoughts from diverse, external or internal (technological, managerial, and scientific) sources.

\section{References}

1. Anderson, Patricia M. "Association of Shopping Center Anchors with Performance of a Nonachor Specialty Chain's Stores." Journal Of Retailing (Summer 1985), pp. 61-74. 
2. Apostolidis, Panos. "Managing Future Retailing Systems." Developments in Marketing Science, Vol. 1 (1978), p. 243.

3. Berkman, Harold W. and Christopher Gilson. Consumer Behavior. Boston, MA: Kent Publishing Company (1986).

4. Berman, Barry and Joel Evans. Retail Management. New York, NY: MacMillan Publishing Co. (1989).

5. Bowles, Samuel. "Setting a Moral Agenda for the Economy" The New York Times (November 6, 1988), p. B2.

6. Butt, Clifford and William Hailes. Introduction to Supermarket Occupations. New York, NY: Delmar, Inc. (1967).

7. Cravens, David, Gerald Hills, and Robert Woodruff. Marketing Decision Making. Homewood, IL: Richard Irwin (1976).

8. Davidson, William, Albert Bates, and Stephan Bass. "The Retail Life Cycle." Harvard Business Review, Vol. 54 (November-December 1976), p. 89-96.

9. Dunkin, Amy, Michael O'Neal, and Stephen Phillips. "Power Retailers," Business Week (December 21, 1987), pp. 86-92.

10. Gregory, Gene, Mike Tharp, and James Bartholomew. "Japan's Third Revolution." World Press Review (March 1982), pp. 23-25.

11. Hagedorn, Ann. "Penney's 'TV Mall' Makes its Hate Humbled Debut." Wall Street Journal (February 6, 1988), p. 6.

12. Hollander, Stanley. "Notes on Retail Accordion." Journal of Retailing (Summer 1966), pp. 29-40.

13. Kaufman, S. "Coping with Rapid Retail Evolution." Journal of Consumer Marketing (Winter 1985), pp. 17-28.

14. Loeb, Walter. "Retailers with Destination Store Image will Prosper in the '90s." Discount Store News (May 1987), pp. 171-172.

15. Markin, Rom and Calvin Duncan. "The Transformation of Retailing Institutions: Beyond the Wheel of Retailing and Life Cycle Theories." Journal of Macromarketing (Spring 1981), pp. 58-66.

16. Markowitz, Arthur. "Carrefour Opens U.S. Hypermarket: Maintains True to European Roots." Discount Store News (February 1988), pp. 1, 100.

17. Mason, Barry, Morris Mayer, and Hazel Ezell. Retailing. Plano, TX: Business Publications, Inc. (1988). 
18. May, Eleanor G., William Ress, and Walter Salmon. "Future Trends in Retailing." Marketing Science Institute (February 1985).

19. McNair, Malcolm P. "Significant Trends and Developments in the Postwar Period." In A. B. Smith, ed., Competitive Distribution is a Free, High Level Economy and its Implication for the University. Pittsburgh, PA: University of Pittsburgh Press (1958).

20. McNair, Malcolm P. and Eleanor A. May. The Evolution of Retail Institutions in the United States. Cambridge, MA: Marketing Science Institute (1976).

21. Miller, Norman. "Rural Retailing: The Last Frontier." Chain Store Age Executive (March 1986), pp. 18-19, 22.

22. Moore, Thomas. "Would You Buy a Car From this Man?" Fortune (April 11, 1988), pp. 72-74.

23. Ouchi, William, and Alfred Jaeger. "Type Z Organization: Stability in the Midst of Mobility." Academy of Management Review (1978), pp. 305-314.

24. Robey, Darrel. Designing Organizations: A Macro Perspective. Homewood, IL: Richard Irwin, Inc. (1982).

25. Toffler, Alvin. The Third Wave. New York, NY: William Morrow (1980).

26. Wienstein, Steve. "The New Safeway." Progressive Grocer, (November 1987), pp. 21-28.

27. Wortzel, Lawrence. "Retailing Strategies for Today's Mature Marketplace." Journal of Business Strategy (Spring 1987), pp. 45-57.

28. Zehr, Leonard. "Mega Mall." Wall Street Journal (October 7, 1985), pp. 1-14.

29. Zif, Jehiel. "A Managerial Approach to Macromarketing." Journal of Marketing (Winter 1980), pp. 36-45. 